\title{
MENINGKATKAN KERJASAMA TIM MELALUI KEPEMIMPINAN YANG EFEKTIF
}

\author{
DESI RATNA YULI \\ desriratnayuliap@gmail.com
}

\begin{abstract}
ABSTRAK
Organisasi dapat dikatakan sukses apabila mempunyai pemimpin yang mampu memimpin secara efektif. Pemimpin tidak hanya di tuntut memimpin secara formal saja, tetapi juga mampu memimpin secara informal yang mana mampu memberikan pengaruh yang kuat pada

bawahannya. Kepemimpinan tentu muncul karena adanya kerjasama yang terjadi.

Kepemimpinan merupakan suatu hal yang seharusnya dimiliki oleh setiap pemimpin organisasi. Efektivitas seorang pemimpin ditentukan oleh kepiawaiannya mempengaruhi dan mengarahkan para anggotanya. Di dalam rangka untuk menguji gaya kepemimpinan yang efektif di Toserba Sinar Mas, Sidoarjo, maka penelitian ini dilakukan untuk membuktikan hubungan antara gaya kepemimpinan dengan semangat dan kegairahan kerja. Tim yang efektif adalah tim yang bisa bekerja sama, saling percaya, dan saling menghargai. Tim dengan kinerja tinggi terdiri dari orang-orang yang benar-benar ahli dibidangnya, tim ini terdiri dari para anggota yang mempunyai keahlian dan kecakapan yang saling melengkapi. Fondasi dari sebuah tim kerja yang sukses dengan mengedepankan hubungan antar manusia, tim efektif adalah saling menghargai satu dengan lainnya, membangun disiplin serta membangun komitmen agar tim dapat bekerja secara efektif.
\end{abstract}

\section{Kata Kunci : Kepemimpinan, kerjasama, tim.}

\section{Latar Belakang}

Tidak ada seorang yang dapat melakukan sesuatu yang besar sendirian, tanpa bantuan orang lain, semua tidakan yang kelihatan dilakukan sendirian sesungguhnya merupakan upaya tim, peribahasa mengatakan dibalik seorang yang cakap selalu ada lagi orang-orang cakap, dan sesungguhnya kerja tim itulah inti dari prestasi kerja. Tidak dipungkiri sering mucul pertanyaan mengapa kita memerlukan tim dalam menuntaskan sebuah pekerja, Perlu dipahami bahwa seiring dengan perubahan karakteristik pekerjaan yang semakin menuntut kerjasama antar berbagai pihak dengan keahlian yang berbeda-beda, untuk itulah perlunya bekerja secara tim efektif.

Kepemimpinan adalah suatu proses dimana individu mempengaruhi kelompok untuk mencapai sebuah tujuan. Tim yang hebat adalah memiliki tujuan yang sama, terdapat kerjasama, komunikasi yang baik serta memiliki komitmen (Maxwell, 1997). Kinerja Tim bergantung pada prestasi kerjasama dan juga prestasi individu, anggota Tim bekerja bersama 
untuk mengumpulkan sumber daya mereka (biasanya dalam hal ini kecakapan) untuk mencapai sasaran-sasarannya. Para anggota tim saling bertanggung jawab dan diberi penghargaan sebagai tim. Tanggungjawab ini berkenaan dengan setiap anggota yang menyumbangkan upaya terbaik untuk membuat kelompok berhasil. Oleh karena itu saling bertanggungjawab ini memerlukan komitmen masing-masing anggota pada setiap anggota yang lain untuk melakukan segala hal yang dapat dilakukan untuk memenuhi tujuan lain. Tim itu sendiri bertanggungjawab atas keseluruhan penyelesaian tugas. Para anggota tim bertanggungjawab untuk memikul bebannya. Di samping itu, setiap anggota tim bertanggungjawab atas tujuan-tujuan tim ini. Saling bertanggung jawab ini juga membantu anggota tim terikat satu sama lain dan mengembangkan kepercayaan yang penting bagi keberhasilan berkesinambungan mereka. Proses dapat menjadi lebih efektif dengan mengumpulkan informasi dan menggunakannya untuk memperbaiki tim mereka. Tim memberi organisasi suatu fleksibilitas yang diperlukan sekarang ini agar lebih responsif terhadap perubahan tim. Sekarang ini pada umumnya tim terlihat dalam struktur yang lebih organik. Tim memiliki sejumlah kelebihan. Tim biasanya bisa bekerja dengan baik ketika keahlian dari berbagai fungsi dilibatkan.

Rumusan Masalah : Definisi kepemimpinan, Definisi kerjasama, Gaya kepemimpinan yang efektif, membangun tin yang efektif

\section{PEMBAHASAN}

\section{A. Definisi kepemimpinan}

Kepemimpinan adalah suatu proses dimana individu mempengaruhi kelompok untuk mencapai sebuah tujuan. Tim yang hebat adalah memiliki tujuan yang sama, terdapat kerjasama, komunikasi yang baik serta memiliki komitmen (Maxwell, 1997). Kepemimpinan memberi nilai pada kehidupan kerja orang lain (Paul Birch, 2001). Seorang pemimpin sejati harus memperhatikan karakter dan integritas, serta memiliki kemampuan dalam metode kepemimpinan, serta menunjukkan perilaku maupun kebiasaan seorang pemimpin (Wahyu, 2005). Dalam bukunya yang amat terkenal, Mengembangkan Kepemimpinan Di Dalam Diri Anda, John C. Maxwell berkata, "Mengubah pemimpin berarti mengubah organisasi. Menumbuhkan pemimpin, menumbuhkan organisasi." Artinya, perusahaan atau organisasi tidak akan berubah dan tidak akan berjalan ke arah yang dicita-citakan, apabila para pemimpinnya 
sendiri, di bagian apapun, tidak berubah dan tidak tumbuh. Sebuah organisasi tidak bisa tumbuh di luar sampai para pemimpinnya sendiri tumbuh di dalam. Jika seluruh unit kepemimpinan berubah secara positif, maka pertumbuhan organisasi atau perusahaan akan terjadi secara otomatis.

Kepemimpinan pada dasarnya tidak bisa berjalan sendirian. Kepemimpinan muncul karena kerja sama dengan orang lain. Tanpa orang lain, tidak ada pemimpin. Dengan demikian, kepemimpinan bukanlah upaya satu orang saja, melainkan melibatkan kerja sama tim. Pergerakan kegiatan kepemimpinan tidak selalu dari atas ke bawah, tetapi juga kepemimpinan menyamping, yaitu membangun kerja sama Tim. Anne Cummings, profesor di bidang manajemen dari universitas Wharton setuju dengan pendapat Useem bahwa semua pegawai bisa menjadi pemimpin. Menurut Cummings, semua karyawan perlu menerapkan "kepemimpinan horizontal." Pendapat ini juga ditunjang oleh Jack Welch, pemimpin legendary di GE, perusahaan raksasa dunia. Welch mengatakan bahwa untuk menjalankan bisnis yang besar dan sukses diperlukan satu tim yang handal yang bisa bekerja sama, saling percaya, dan saling menghargai. Tanpa ketiga kualitas ini, akan sulit bagi sebuah perusahaan untuk mendongkrak prestasinya agar bisa tampil prima di kancah persaingan bisnis yang semakin ketat.

Sebuah kegiatan usaha tidak bisa dijalankan oleh bagian penjualan saja, bagian produksi saja, bagian keuangan saja, bagian SDM saja, ataupun bagian layanan masyarakat saja. Semua bagian ini harus bisa bekerja sama untuk menghasilkan produk dan jasa yang bisa memuaskan pasar, yang pada akhirnya bisa memberi nilai bagi seluruh kegiatan usaha, dan tentunya bagi para pemegang saham. Semua ini bisa berjalan jika ada kerja sama tim.

\section{B. Definisi Kerja sama tim}

kerja sama adalah sebuah sistem pekerjaan yang kerjakan oleh dua orang atau lebih untuk mendapatkan tujuan yang direncanakan bersama. Kerja sama dalam tim kerja menjadi sebuah kebutuhan dalam mewujudkan keberhasilan kinerja dan prestasi kerja. Kerja sama dalam tim kerja akan menjadi suatu daya dorong yang memiliki energi dan sinergisitas bagi individu-individu yang tergabung dalam kerja tim. Komunikasi akan berjalan baik dengan dilandasi kesadaran tanggung jawab tiap anggota. Sebagaimana yang dinyatakan Tracy (2006) bahwa, Kerja sama dapat 
meningkatkan komunikasi dalam kerja tim di dalam dan di antara bagian-bagian perusahaan. Kerja sama mengumpulkan bakat, berbagi tugas dan tanggung jawab untuk mencapai tujuan bersama. Kerja sama dilakukan oleh sebuah tim lebih efektif daripada kerja secara individual. Tim adalah suatu unit yang terdiri atas dua orang atau lebih yang berinteraksi dan mengoordinasi kerja mereka untuk tujuan tertentu. Definisi ini memiliki tiga komponen. Pertama, dibutuhkan dua orang atau lebih. Kedua, orang - orang dalam sebuah tim memiliki interaksi regular. Ketiga, orang orang dalam sebuah tim memiliki tujuan kinerja yang sama. Sebagaimana yang dikemukakan Ernita (Ermita, 2012) Tujuan dari sebuah organisasi tidak akan tercapai secara optimal apabila pegawainya melaksanakan tugas sacara sendiri-sendiri tanpa adanya kerjasama.

\section{Gaya Kepemimpinan yang Efektif}

1. The Anthoractic Leader

Seorang pemimpin yang otokratik menganggap bahwa semua kewajiban untuk mengambil keputusan, untuk menjalankan tindakan dan untuk mengarahkan tindakan, dan untuk mengarahkan, memberi motivasi dan mengawasi bawahannya terpusat ditangannya. Seorang pemimpin yang otokratik mungkin memutuskan, dan punya perasaan bahwa bawahannya tidak mampu untuk beranggapan mempunyai posisi yang kuat untuk mengarahkan dan mengawasi pelaksanaan pekerjaan dengan maksud untuk meminimumkan penyimpangan dari arah yang ia berikan.

2. The Pacitipative Leader

Apabila seseorang pemimpin menggunakan gaya partisipasi ia menjalankan kepemimpinan dengan konsultasi. Ia tidak mendelegasikan wewenangnya untuk membuat keputusan akhir dan untuk memberikan pengarahan tertentu kepada bawahannya mengenai keputusan yang akan diambil. Ia akan secara serius mendengarkan dan menilai pikiran-pikiran para bawahannya dan menerima sumbangan pikiran mereka. Sejauh pemikiran tersebut bisa dipraktekkan. Pemimpin dengan gaya partisipatif akan mendorong kemampuan mengambil keputusan daripada bawahannya sehingga pikiran-pikiran mereka akan selalu meningkat dan semakin matang. Para bawahannya juga didorong meningkatkan kemampuan mengendalikan diri dan menerima tanggung jawab yang lebih besar. Pemimpin akan lebih suportif dalam kontak dengan para bawahan dan bukan 
menjadi bersikap diktator. Meskipun tentu saja, wewenang terakhir dalam pengambilan keputusan terletak pada pimpinan.

3. The Free Rein Leader

Dalam gaya kepempimpinan "free rein" pemimpin mendelegasikan wewenang untuk mengambil keputusan kepada para bawahannya dengan agak lengkap. Pada prinsipnya pimpinan akan mengatakan "inilah pekerjaan yang harus saudara lakukan. Saya tidak peduli bagaimana kalau mengerjakannya, asalkan pekerjaan tersebut bisa diselesaikan dengan baik". Disini pimpinan menyerahkan tanggung jawab atas pelaksanaan pekerjaan tersebut kepada para bawahannya. Dalam artian pimpinan menginginkan agar para bawahan bisa mengendalikan diri mereka sendiri dalam menyelesaikan pekerjaan tersebut,dan hanya para bawahan dituntut untuk memiliki kemampuan/keahlian yang tinggi.

\section{Membangun Tim Efektif}

Dalam upaya membangun tim Efektif adalah kesamaan Visi, misi dan tujuan yang ingin dicapai dengan terus melakukan brainstorming agar kesepakatan bersama dapat tercapai. Salah satu aspek yang dibangun adalah pembagian tugas yang jelas sehingga masing-masing anggota mengerti kewajibannya. Selanjutnya akan dapat menumbuh kembangkan rasa tanggungjawab dan komitmen dalam diri anggota tim. Di dalam sebuah tim tetap dibutuhkan seorang pemimpin yang mampu menjadi motivator dan membangun suasana kerja yang kondusif dari seorang pemimpin yang dapat berpikir jernih dan bertanggung jawab.

Tantangan utama yang berhubungan dengan aspek kepemimpinan Tim adalah membangun budaya yang kondusif serta menciptakan atmosfer yang mendukung kerja tim (Dubrin, 2005). Tim kerja merupakan kompetensi penting untuk menuju kesuksesan. Tantangan ini mirip dengan tantangan membangun kultur yang tepat untuk memotivasi orang. Strategi yang dianjurkan untuk pemimpin tim adalah mempromosikan pandangan yang mengakui bahwa bekerja sama secara efektif merupakan standar perilaku yang diharapkan. Membangun kultur atau norma teamwork akan sulit ketika ada kultur individualisme yang kuat di dalam sebuah organisasi. Pemimpin tim yang percaya kepada teamwork biasanya memiliki posisi yang lebih baik untuk membangun kultur teamwork. Tim dengan kinerja tinggi pada umumnya heterogen. Artinya, tim yang mencapai tingkat kinerja yang tinggi tidak 
terdiri dari orang-orang yang benar-benar sama. Melainkan, tim ini terdiri dari para anggota yang mempunyai kecakapan-kecakapan yang saling melengkapi. Mereka memerlukan kecakapan pemecahan masalah dan pembuatan keputusan. Para anggota harus mampu mengenali masalah dan peluang, kemudian memilih solusi. Kecakapan hubungan antarpribadi diperlukan untuk berkomunikasi, memecahkan konflik dan berinteraksi secara efektif dengan para anggota tim. Ketika tim berkembang kita harus memastikan bahwa para anggota mempunyai lebih dari masing-masing kecakapan ini. Keanggotaan tim dengan kecakapan yang saling melengkapi penting dalam mencapai kreativitas (Patricia Buhler, 2004).

\section{KESIMPULAN}

Kepemimpinan adalah suatu proses dimana individu mempengaruhi kelompok untuk mencapai sebuah tujuan. Tim yang hebat adalah memiliki tujuan yang sama, terdapat kerjasama, komunikasi yang baik serta memiliki komitmen (Maxwell, 1997). Kinerja Tim bergantung pada prestasi kerjasama dan juga prestasi individu, anggota Tim bekerja bersama untuk mengumpulkan sumber daya mereka (biasanya dalam hal ini kecakapan) untuk mencapai sasaran-sasarannya. Kepemimpinan pada dasarnya tidak bisa berjalan sendirian. Kepemimpinan muncul karena kerja sama dengan orang lain. Tanpa orang lain, tidak ada pemimpin. Dengan demikian, kepemimpinan bukanlah upaya satu orang saja, melainkan melibatkan kerja sama tim. Pergerakan kegiatan kepemimpinan tidak selalu dari atas ke bawah, tetapi juga kepemimpinan menyamping, yaitu membangun kerja sama Tim. Dalam upaya membangun tim Efektif adalah kesamaan Visi, misi dan tujuan yang ingin dicapai dengan terus melakukan brainstorming agar kesepakatan bersama dapat tercapai. Salah satu aspek yang dibangun adalah pembagian tugas yang jelas sehingga masing-masing anggota mengerti kewajibannya. 


\section{Referensi}

Yun Iswanto, 2002. Buku Materi Pokok, Manajemen SDM, Jakarta : BPK-Pusat Penerbitan UT.

Barry Cushway, Manajemen Sumber Daya Manusia (Perencanaan, Analysis, Kinerja, Penghargaan ), PT. Elex Media Komputindo Kelompok Gramedia, Jakarta, 1996.

John Maxwell, Be a People Person, Interaksara, Batam, 1999.

Ermita. (2012). Hubungan antar manusia dan semangat kerja karyawan. Pedagogi, Jurnal Ilmiah Ilmu Pendidikan, XII(2), 70-81. Retrieved from https://scholar.google.co.id/citations?user=QhCIbi0AAAAJ\&hl=id\&oi=sra\#d=gs_md_c itad\&u=\%2Fcitations\%3Fview_op\%3Dview_citation\%26hl\%3Did\%26user\%3DQhCIbi 0AAAAJ\%26citation_for_view\%3DQhCIbi0AAAAJ\%3ALkGwnXOMwfcC\%26tzom $\% 3 \mathrm{D}-420$ 